\title{
Epidemiology of rabies in Oman: a retrospective study (1991-2013)
}

Al-Abaidani IA, ${ }^{7}$ Al-Abri SA, ${ }^{7}$ K.P. Prakash, ${ }^{1}$ M. Hassan Hussain, ${ }^{2}$ M. Hammad Hussain ${ }^{2}$ and A.H. Al Rawahi ${ }^{2}$

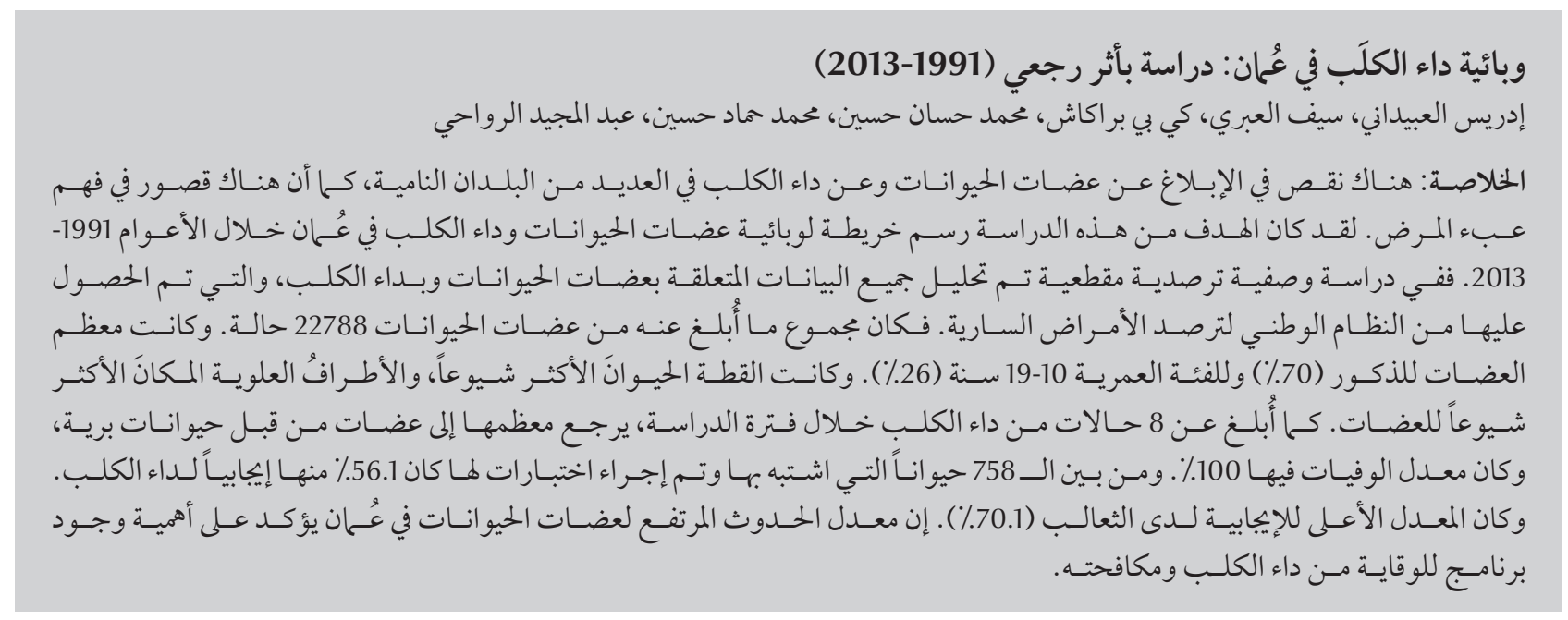

ABSTRACT Animal bites and rabies are under-reported in many developing countries and there is poor understanding of the disease burden. The aim of this study was to map the epidemiology of animal bites and rabies in Oman over the period 1991-2013. In a cross-sectional, descriptive, surveillance-based study, all data about animal bites and rabies from the national communicable disease surveillance system were analysed. A total of 22788 cases of animal bites were reported. Most bites were to males (70\%) and the 10-19 year age group (26\%). Cats were the most common animal and upper extremities were the most common bite site. There were 8 rabies cases reported during the study period, mostly due to bites from wild animals, with $100 \%$ mortality. Of 758 suspected animals tested, $56.1 \%$ were positive for rabies; foxes had the highest positivity rate $(70.1 \%)$. The high incidence of animal bites in Oman emphasizes the importance of a rabies prevention and control programme.

\section{Épidémiologie de la rage à Oman : étude rétrospective (1991 - 2013)}

RÉSUMÉ Les morsures d'animaux et la rage font l'objet d'une sous-notification dans de nombreux pays en développement où la charge de la maladie reste mal comprise. L'objectif de la présente étude était de cartographier l'épidémiologie des morsures d'animaux et de la rage à Oman entre 1991 et 2013. Dans une étude transversale et descriptive reposant sur la surveillance, toutes les données sur les morsures d'animaux et la rage extraites du système national de surveillance des maladies transmissibles ont été analysées. Au total, 22788 cas de morsures d'animaux avaient été notifiés. La plupart des victimes de morsures étaient de sexe masculin (70 \%) et appartenaient à la tranche d'âge des 10-19 ans (26\%). L'animal mordeur le plus fréquent était le chat et les membres supérieurs représenteraient le site le plus souvent mordu. Pendant la période de l'étude, huit cas de rage ont été rapportés, essentiellement dus à des morsures par des animaux sauvages, avec un taux de mortalité de $100 \%$. Sur les 758 animaux suspects dépistés, 56,1\% étaient positifs pour la rage ; les renards avaient le pourcentage positif le plus élevé $(70,1 \%)$. Cette forte incidence des morsures animales à Oman souligne l'importance d'un programme de prévention et de lutte concernant la rage. 


\section{Introduction}

Rabies is an enzootic disease caused by the rabies virus (a species of lyssavirus) and, in the absence of pre- or post-exposure vaccination, is often fatal. The main reservoirs of the virus are wild and domestic canids (dogs, wolves, foxes, etc.) and bats (1). Transmission to humans occurs through contact of the animal's infected saliva with open wounds, typically through an animal bite. A large multi-centre study in India reported that dog bites constituted the majority of all incidents, while bites from other animals such as monkeys, cats, fox bats and rabbits comprised the rest (2).

Rabies occurs in more than 150 countries worldwide. It is estimated that more than 60000 people die of rabies every year, mostly in Asia, with about 1.2 million disability-adjusted lifeyears (DALYs) lost in the continent, followed by Africa with 23700 deaths annually. India is reported to have the highest incidence of rabies globally, with 20565 human deaths occurring annually (most cases being reported in rural communities). Initial estimates suggest that in the Middle East rabies is responsible for 350 deaths annually (95\% CI: 270-450) and 13100 DALYs (95\% CI: 11 100-15 900). As many as 40\% of the people who are bitten by suspect rabid animals are children under the age of 15 years $(3,4)$.

Rabies is a serious enzootic disease throughout the Middle East, notably in Jordan, the Syrian Arab Republic, Lebanon and the Islamic Republic of Iran (5). In Asia, 8 countries have been reported as rabies-free: Japan, Malaysia, Hong Kong, Singapore, Taiwan, Qatar, Bahrain and the United Arab Emirates (UAE) (6). Few published data are available about animal bites and rabies epidemiology among humans in Oman or even in the Middle East more generally, and more investigation into the scale of the burden of rabies is needed in the region. Prior to August
1990, there were no official records of rabies cases in Oman and the country was believed to be rabies-free. The first reported cases in Oman were of 2 expatriate workers who were originally bitten by dogs outside Oman in 1983 and 1984 (7). All suspected animal samples examined in the laboratory were found to be negative for rabies virus during the 1980s. Human rabies was not known or reported. In August 1990 the first human case of rabies contracted in Oman was reported in a schoolboy following a fox bite. Subsequently, epidemiological investigations were undertaken and established the presence of sylvatic rabies in Oman. Out of 30 animals subjected to laboratory tests as many as 21 were found to be positive and the majority were red foxes (Vulpes vulpes). Overall, $63 \%$ of submitted samples were confirmed as rabies cases in animals during 2006-10, which confirms the spread of sylvatic rabies in Oman (8).

In the last 3 decades substantial progress in the control of several priority diseases has been made in Oman. National surveillance of animal bites and rabies was established in December 1990, with cases of group A disease required to be notified within 24 hours and given immediate management (9). The anti-rabies vaccination policy was implemented in 1990 with the use of human diploid cell culture vaccine in post-exposure treatment. From 2004, in place of this, purified Vero cell rabies vaccine was introduced. Human rabies immunoglobulin is also given when there are specific indications, followed by routine vaccination in some circumstances. Pre-exposure treatment for the high-risk groups of veterinarians and animal handlers is done by the Omani Ministry of Agriculture and Fisheries (MAF) (9).

The aim of this study was to map the epidemiology of animal bites and rabies in Oman over the period from March 1991 (when the national communicable disease surveillance system was launched) to 2013.

\section{Methods}

\section{Study design and data sources}

This first part of the study was a retrospective study of surveillance data from all human cases of animal bites and rabies reported between the years 1991 and 2013. The communicable diseases case notification form (PR-7) was used to collect the human data by the communicable diseases units in the governorates and compiled centrally by the Department of Communicable Disease Surveillance and Control (10). The following data were recorded for each animal bite case: age, sex, bite history and laboratory results.

The second part of the study was an analysis of the prevalence of rabies virus in suspected animals. The animal rabies data were collected in collaboration with the MAF. The Omani Ministry of Health $(\mathrm{MOH})$ works closely with the MAF to identify any increase in cases of animal rabies as an early warning in the surveillance of cases of animal bites and human rabies. The Animal Health Research Centre in MAF has the facility for testing animal samples and mapping of animal rabies in Oman. Samples from animals suspected of being rabid (based on clinical signs) were forwarded to the virology section for diagnosis.

\section{Diagnosis of rabies}

The diagnosis of rabies in humans was based entirely on clinical presentation.

Diagnosis of rabies in tested animals was by direct fluorescent antibody technique (DFAT). A positive reaction was demonstrated by visualization of bright apple-green fluorescent particles ranging in size and morphology from dust-like particles to prominent cytoplasmic inclusion bodies (Negri bodies). For histopathology, tissue samples from the cerebral hemispheres, cerebellum and medulla oblongata of the suspected animals were collected and fixed in $10 \%$ formal saline. The tissues were processed to obtain $4-5 \mu \mathrm{m}$ 
thick paraffin-embedded sections and stained with haematoxylin and eosin. Finally, samples positive on DFAT or histopathology were subjected to reverse-transcription polymerase chainreaction testing (7).

\section{Data analysis}

The data collected for this survey were entered into a computerized database using statistical software Epi Info 2000, version 3.3.1. The data were analysed statistically using SPSS, version 19 software. The results were expressed as means for age, as rates for animal bites and proportions for other parameters. Chi-squared tests were applied to test for significance and a $P$-value of 0.05 was considered significant at $95 \%$ confidence level.

\section{Results}

\section{Animal bites in Oman}

During the survey period (1991 to 2013), 22788 people were notified to the registry as being treated for animal bites. The incidence of animal bites in Oman increased from 46.5 per 100000 in 1991 to 56.6 per 100000 population in 1999. However, there was a gradual decrease in the number of animal bites after the year 2005 (Figure 1).

Of the animal bite cases, 15938 (70.1\%) were males and 6784 (29.9\%) were females. The majority of cases were among the 10-19 year age group (21.5\%), followed by 20-29 years (16.5\%) (Figure 2). The majority of the cases were reported from Muscat governorate (21.1\%) (Figure 3).

Upper extremities (hands) were the most common bite locations (48.9\%), followed by the lower extremities (35.4\%), body (4.4\%) and head and face $(7.0 \%)$. Bites from cats were the most common ( 11002 cases, $48.3 \%$ ), followed by dogs (35.2\%), foxes (5.2\%), wolves $(0.2 \%)$ and other animals $(5.6 \%)$ (note: the total number does not equal 22788 because of missing information on the site and type of biting animal).

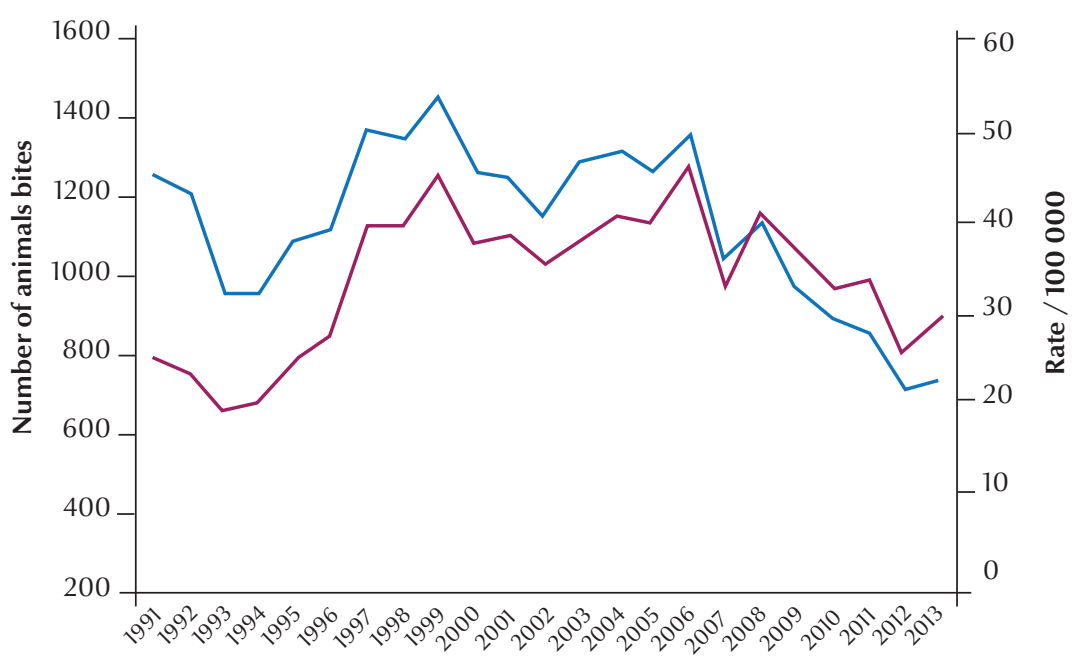

Figure 1 Number of reported cases of animal bites to humans and rate per 100000 population in Oman from 1991 to 2013

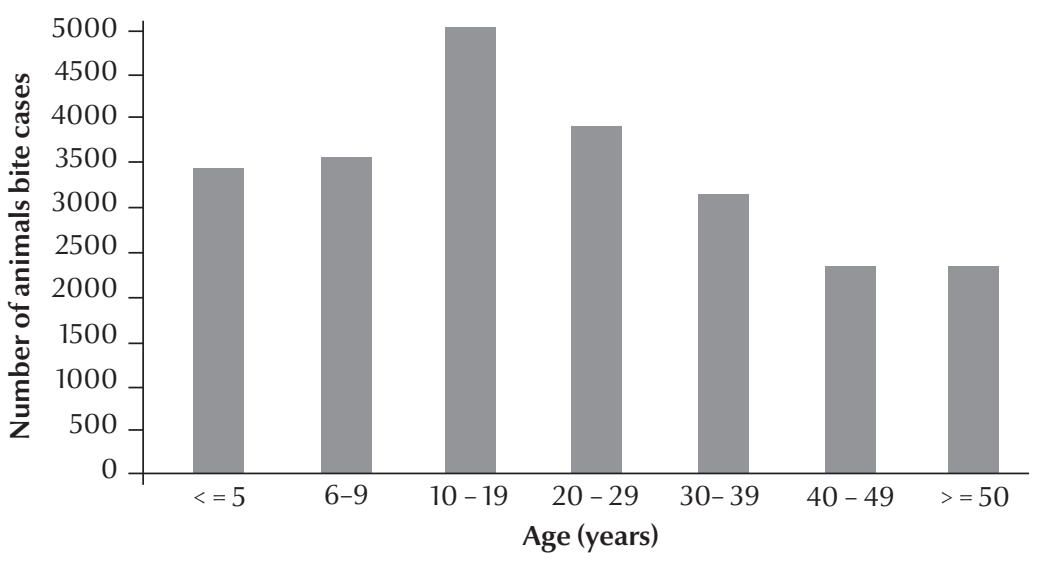

Figure 2 Total number of reported cases of animal bites to humans in Oman from 1991 to 2013, according to age of victim

\section{Human rabies cases in Oman}

During the study period 8 cases of rabies from animal bites were reported in humans. Table 1 depicts the line-list of rabies cases in Oman. All the cases were in Omanis who had been bitten by a wild animal (fox/wolf) except for 1 expatriate (Bangladeshi) with a history of dog bite in the native country and diagnosed in Oman. All the subjects died thereafter (mortality rate 100\%).

\section{Animal rabies cases in Oman}

Table 2 shows that the number of positive animal rabies cases by governorate/ region increased between the years 2006 to 2013. After laboratory confirmation, 425 of the 758 samples from suspected animals, submitted from 35 wilayat (districts), were found to be positive (56.1\%). The distribution by governorate showed that the overall rate of positivity was highest in Al Dakhiliyah governorate (47.3\%) and the positivity rate was more or less similar across the other governorates $\left(\chi^{2}=12.72, \mathrm{df}=7, P\right.$ $=0.08)$. The geographical distribution of percentage positive animal rabies cases across different districts of Oman are shown in Figure 4. 


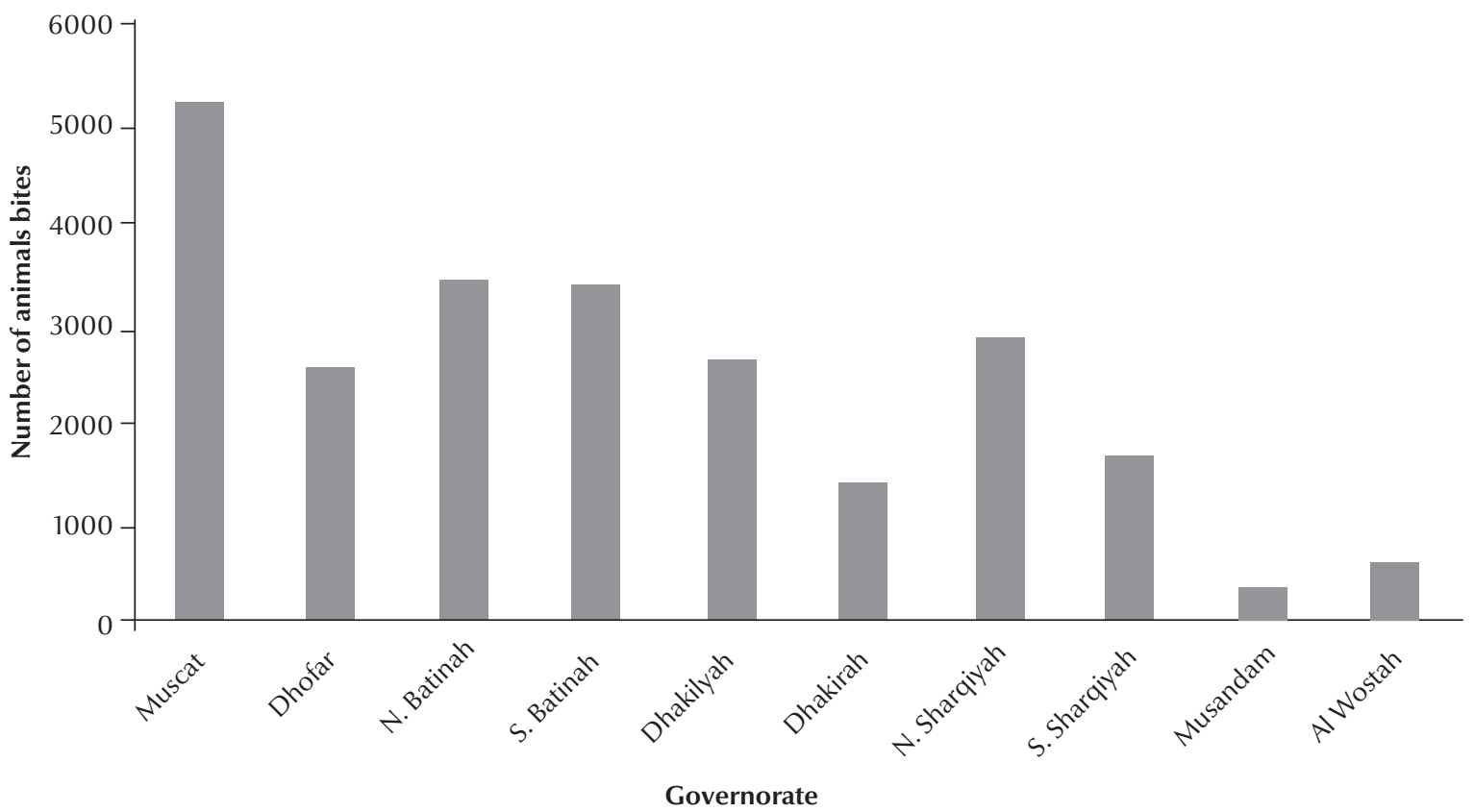

Figure 3 Distribution of total number of reported cases of animal bites to humans in Oman from 1991 to 2013, according to governorate where bite occurred

Table 3 depicts the positive animal rabies cases by type of animal from 2006 to 2013. The overall rate of positivity was highest among foxes $(70.1 \%)$, followed by camels $(59.7 \%)$, small ruminants $(57.1 \%)$ and $\operatorname{dogs}(28.5 \%)\left(\chi^{2}=21.52\right.$, $\mathrm{df}=4, P<0.01)$.

\section{Discussion}

During the study period 22788 people reported animal bites in Oman. The overall incidence of animal bites was 38.6 (96\% CI: 22.3 to 50.0) per 100000 population during the study period. Worldwide the reported incidence of animal bites varies from 35.1 to 241 per 100000 in different studies $(10,11)$. The different results may be due to differences across countries in animalhuman relationships (pet animals, living close to the forest or wildlife, sleeping outdoors, etc.). One limitation of this study is that the surveillance data could be an underestimate of the problem of animal bites in Oman because of unreported minor bites or scratches.

In the current research, $70.1 \%$ of animal bites were to males and $29.9 \%$ to females. These proportions are similar to studies conducted in Ilam, Tehran and Kerman provinces of the Islamic Republic of Iran, where it was reported that $68.3 \%, 79.2 \%$ and $73.5 \%$ of animal bites respectively were to men (11-14). On the other hand, the results of a study performed in the United States of America (USA) indicated that women were more frequently injured by animals as compared to men (15). Another study, performed in Puerto Rico, showed that the rate of animal bites was similar in both women and men (16). In the present study, the age

\begin{tabular}{|c|c|c|c|c|c|c|}
\hline $\begin{array}{l}\text { Reporting month } \\
\text { and year }\end{array}$ & Region/governorate & Age (years) & Sex & Nationality & Type of animal & Site of bite \\
\hline Apr 1990 & Dhahira & School boy & Male & Omani & Fox & (Unrecorded) \\
\hline Nov 1991 & Dhofar & 55 & Female & Omani & Wolf & Face \\
\hline Feb 1992 & Dhofar & 0.05 & Female & Omani & Fox & Scalp \\
\hline Aug 1993 & North Batinah & 30 & Male & Bangladeshi & Dog & Left thumb \\
\hline May1997 & North Sharqiya & 17 & Female & Omani & Fox & Upper lip \\
\hline Dec 1998 & Dhofar & 60 & Male & Omani & Fox & Forehead \\
\hline Jan 1999 & Buraimi & 13 & Female & Omani & Wild cat (lynx) & Face \\
\hline Sept 2003 & Dhofar & 48 & Female & Omani & Fox & Lower extremities \\
\hline
\end{tabular}




\begin{tabular}{|c|c|c|c|c|}
\hline $\begin{array}{l}\text { Table } 2 \text { Number of su } \\
\text { rabies from } 2006 \text { to }\end{array}$ & $\begin{array}{l}\text { d rabid } \\
\text { y gover }\end{array}$ & $\begin{array}{l}\text { Is exan } \\
\text { of Om }\end{array}$ & and fou & positive for \\
\hline Governorate & Tested & Posit & r rabies & Distribution by \\
\hline & No. & No. & $\%$ & $\%$ \\
\hline Al Dhahira & 44 & 17 & 38.6 & 4.0 \\
\hline Al Buraimia & 1 & 1 & 100.0 & 0.2 \\
\hline Al Batinah North & 166 & 89 & 53.6 & 20.9 \\
\hline Al Batinah South & 17 & 10 & 58.8 & 2.4 \\
\hline Al Dakhiliyah & 342 & 201 & 58.8 & 47.3 \\
\hline Ash Sharqiyah North & 32 & 22 & 68.8 & 5.2 \\
\hline Ash Sharqiyah South & 99 & 52 & 52.5 & 12.2 \\
\hline Dhofar & 39 & 26 & 66.7 & 6.1 \\
\hline Muscat & 18 & 7 & 38.9 & 1.6 \\
\hline Total & 758 & 425 & 56.1 & 100.0 \\
\hline
\end{tabular}

${ }^{a}$ The case from Buraimi (which was previously part of Dhahira) was included with Dhahira cases for $\chi 2$ testing because of the small numbers $(\chi 2=12.72, d f=7, P=0.08)$.

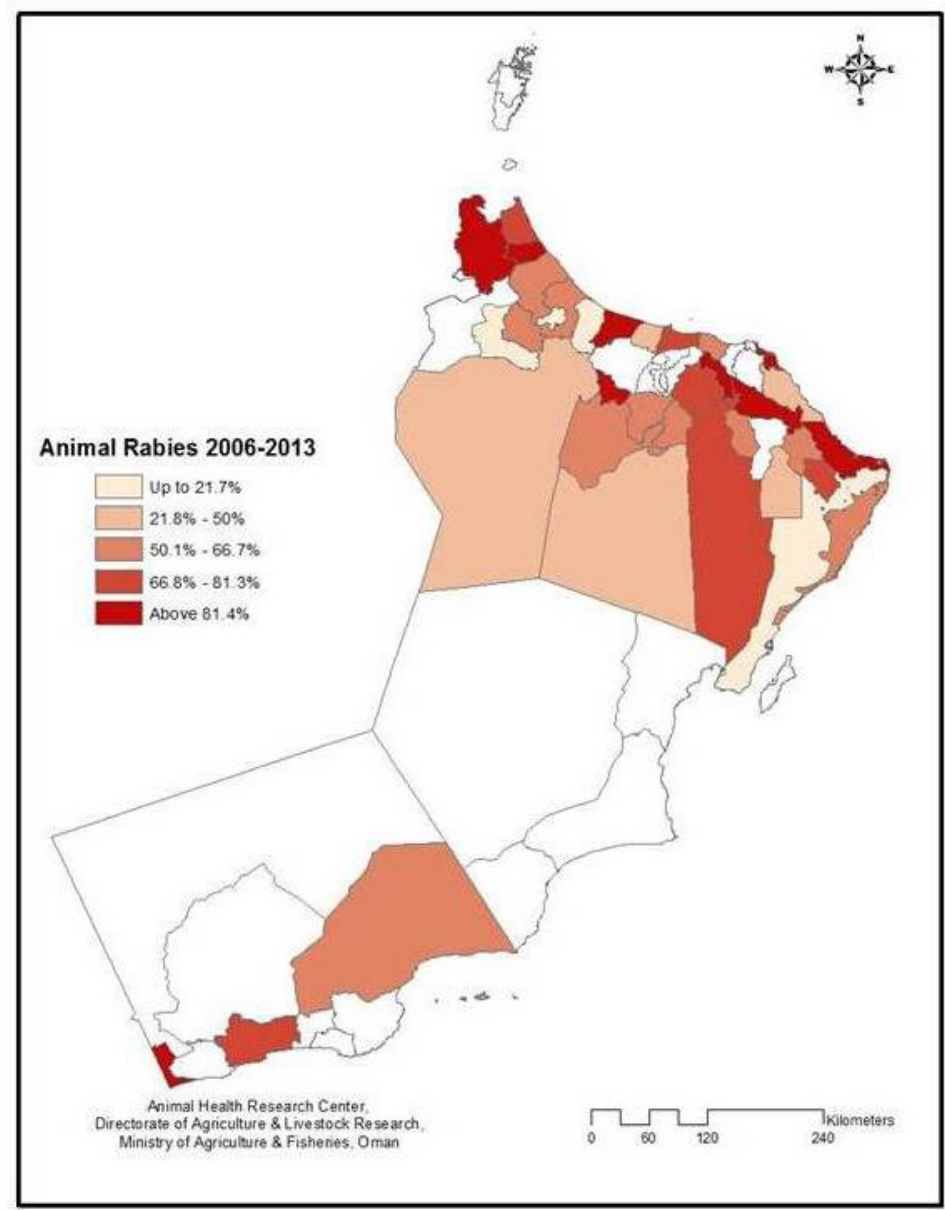

Figure 4 Animal rabies cases in Oman from 2006 to 2013 showing geographical distribution of percentage of tested animals which were positive for rabies in different governorates/districts group most affected by animal bites was 10-19 years old (21.5\%). Similarly, a study performed in Kerman in the Islamic Republic of Iran showed the most commonly affected age group was the 10-19 year olds. However, the Puerto Rico study showed that people aged 18 years or older had the highest rate of animal bites $(14,16)$. The reason why bites are common in young males in Oman may be due to more frequent outdoor activity, playful nature, risk behaviour and close association with the animals traditionally by this group.

In our study, upper extremities were the most frequent bite site (48.9\%), followed by lower extremities (35.4\%) and face $(5.3 \%)$. In contrast, the lower extremities were the most common site of bite in various studies in other countries $(12,14,17)$. In the present study, the highest percentage of animal bites were associated with cats (48.3\%), followed by dogs (35.2\%) and foxes (5.2\%). In comparison, in studies conducted in Tehran, Khuzestan and Rafsanjan in the Islamic Republic of Iran dogs were the most common animal involved, followed by cats $(11,13,17,18)$. Similarly, animal bites were more frequently reported from cats than dogs in the USA since 1990 and their bites pose a greater threat to the human population. This difference could be due to religious reasons and different cultural practices in Oman (dogs are usually not kept as pets and their presence around humans is usually discouraged).

Only 8 human rabies cases were reported in Oman during the study period. The last case was in the year 2003. This low incidence could be due to the combined effort of good animal bites surveillance, universal post-exposure prophylaxis and the low rate of dog rabies in Oman (28.5\% of dogs versus $70.1 \%$ of foxes tested).

A national rabies control programme in Oman needs the collaboration of different governmental sectors such as $\mathrm{MOH}, \mathrm{MAF}$ and the Royal Oman Police to prevent animal bites 


\begin{tabular}{|c|c|c|c|c|c|c|c|c|c|c|}
\hline \multirow[t]{2}{*}{ Animal } & \multicolumn{8}{|c|}{ No. of animal rabies cases in Oman (positive/tested) } & \multirow[t]{2}{*}{ Total } & \multirow{2}{*}{$\begin{array}{c}\% \\
\text { positive }\end{array}$} \\
\hline & 2006 & 2007 & 2008 & 2009 & 2010 & 2011 & 2012 & 2013 & & \\
\hline Fox & $13 / 21$ & $6 / 8$ & $8 / 8$ & $8 / 11$ & $2 / 2$ & $4 / 5$ & $3 / 3$ & $3 / 3$ & $47 / 61$ & 70.1 \\
\hline Dog & $0 / 0$ & $0 / 0$ & $0 / 0$ & $0 / 3$ & $1 / 2$ & $1 / 1$ & $0 / 1$ & $0 / 0$ & $2 / 7$ & 28.5 \\
\hline Cat & $0 / 0$ & $0 / 0$ & $0 / 0$ & $0 / 1$ & $0 / 0$ & $0 / 1$ & $0 / 0$ & $0 / 6$ & $0 / 8$ & 0.0 \\
\hline Camel & $1 / 3$ & $5 / 7$ & $12 / 12$ & $4 / 6$ & $7 / 11$ & $9 / 14$ & $2 / 11$ & $0 / 3$ & $40 / 67$ & 59.7 \\
\hline Sheep/goat & $11 / 27$ & $42 / 57$ & $66 / 92$ & $35 / 51$ & $44 / 71$ & $66 / 108$ & $44 / 106$ & $4 / 34$ & $312 / 546$ & 57.1 \\
\hline Other & $1 / 7$ & $12 / 30$ & $1 / 4$ & $0 / 6$ & $0 / 4$ & $5 / 8$ & $3 / 7$ & $0 / 0$ & $22 / 66$ & 33.3 \\
\hline
\end{tabular}

and rabies. Appropriate public education, prevention strategies and vaccination of all domestic animals, especially dogs, along with pre- and post- exposure treatment may reduce the number of human and animal rabies cases in Oman. There remain a number of challenges to reaching wild animals (red foxes) and stray animals in monitoring and oral vaccination by means of baits; these include the difficult terrain and climate and the risk of human contact with baits. Mapping of animal bites and confirmed rabies cases may help to identify the geographical regions and species at higher risk of disease. For example, remote sensing and satellite imagery can be used to study the ecology of foxes in order to identify areas of high population density and to plan control efforts. Molecular investigation of the strain $(\mathrm{s})$ of rabies in Oman would further aid the design of control strategies (7).

Incorporation of rabies vaccination for children into the existing expanded programme of immunization and the elimination of rabies in Oman are challenges that remain. Enhanced efforts towards the more realistic aim of elimination of rabies in dogs, with the resultant reduction in the risk of human mortality, is essential. We should focus on a collaborative multidisciplinary initiative towards combating rabies through the mass vaccination of dogs. Continued research towards the development of novel diagnostic techniques and newer vaccines and techniques are also desired. The World Health Organization, Organisation for Animal Health, and the Food and Agricultural Organization have initiated a joint effort to achieve the elimination of human rabies and control of the disease in animals through awareness and education, vaccination of dogs, post-exposure prophylaxis and surveillance (19).

\section{Acknowledgements}

We are grateful to all governorate epidemiologists and hospital staff for their invaluable contribution and support.

\section{Funding: None.}

Competing interests: None declared.

\section{References}

1. Heymann DL. Control of communicable diseases manual. 19th edition. Washington (DC): American Public Health Association; 2008. pp. 439.

2. Ichhpujani RL, Mala C, Veena M, Singh J, Bhardwaj M, Bhattacharya $\mathrm{D}$, et al. Epidemiology of animal bites and rabies cases in India. A multicentric study. J Commun Dis. 2008 Mar;40(1):27-36. PMID:19127666

3. WHO Expert Consultation on Rabies. Second report 2013. Geneva: World Health Organization, 2013 (WHO Technical Report Series 982) (http://apps.who.int/iris/bitstre am/10665/85346/1/9789240690943_eng.pdf, accessed 25 May 2015).

4. Knobel DL, Cleaveland S, Coleman PG, Fèvre EM, Meltzer MI, Miranda ME, et al. Re-evaluating the burden of rabies in Africa and Asia. Bull World Health Organ. 2005 May;83(5):360-8. PMID:15976877

5. David D, Hughes GJ, Yakobson BA, Davidson I, Un H, Aylan $\mathrm{O}$, et al. Identification of novel canine rabies virus clades in the Middle East and North Africa. J Gen Virol. 2007 Mar;88(Pt 3):967-80. PMID:17325371

6. Beran GW, Steele JH. Rabies and infections by rabies related virus. In: Beran GW, editor. Handbook of zoonoses. 2nd ed. Boca Raton, Ann Arbor: CRC Press, Inc.; 1994. pp. 307-57.
7. Wildlife rabies in Oman and the United Arab Emirates. Wkly Epidemiol Rec. 1992 Mar 6;67(10):65-8. PMID:1550721

8. Hussain MH, Ward MP, Body M, Al-Rawahi A, Wadir AA, AlHabsi S, et al. Spatio-temporal pattern of sylvatic rabies in the Sultanate of Oman, 2006-2010. Prev Vet Med. 2013 Jul 1;110(34):281-9. PMID:23375085

9. Communicable disease surveillance and control. A standard operating procedures manual. 2nd ed. Muscat: Sultanate of Oman Ministry of Health, 2005 (http://www.cdscoman.org/ uploads/cdscoman/CDS\%20Manual.pdf, accessed 25 May 2015).

10. Turner GS. A review of the world epidemiology of rabies. Trans R Soc Trop Med Hyg. 1976;70(3):175-8. PMID:790669

11. Knobel Freud H, López Colomés JL, Serrano Sáinz C, Hernández Vidal P. [Animal bites. Study of 606 cases]. Rev Clin Esp. 1997 Aug;197(8):560-3. PMID:9312793

12. Bahonar AR, et al. A Study of Rabies and the Frequency of Animal Bites in the Province of Ilam, 1994-2004 [in Persian]. Iran J Epidemiol. 2008;4:47-51.

13. Eslamifar A, Ramezani A, Razzaghi-Abyaneh M, Fallahian V, Mashayekhi P, Hazrati M, et al. Animal bites in Tehran, Iran. Arch Iran Med. 2008 Mar;11(2):200-2. PMID:18298299 
14. Rezaeinasab M, et al. The prevalence of rabies and animal bites during 1994 to 2003 in Kerman province, southeast of Iran. Iran J. Vet Res. 2007;8:343-50.

15. Freeman AJ, Senn DR, Arendt DM. Seven hundred seventy eight bite marks: analysis by anatomic location, victim and biter demographics, type of crime, and legal disposition. J Forensic Sci. 2005 Nov;50(6):1436-43. PMID:16382842

16. Quiles Cosme GM, Pérez-Cardona CM, Aponte Ortiz FI. [Descriptive study of animal attacks and bites in the municipality of San Juan, Puerto Rico, 1996-1998]. P R Health Sci J. 2000 Mar;19(1):39-47. PMID:10761204
17. Alavi SM, Alavi L. Epidemiology of animal bites and stings in Khuzestan, Iran, 1997-2006. J Infect Public Health. 2008;1(1):51-5. PMID:20701846

18. Sheikholeslami NZ, Rezaeian M, Salem Z. Epidemiology of animal bites in Rafsanjan, southeast of Islamic Republic of Iran, 2003-05. East Mediterr Health J. 2009 Mar-Apr;15(2):455-7. PMID:19554994

19. FAO, OIE and WHO unite to eliminate human rabies and control the disease in animals. 28 September 2013. Geneva: World Health Organization; 2103 (http://www.who.int/rabies/ WRD_2013_Statement_Eng.pdf?ua=1 accessed 21 May 2015). 